\title{
c-kit expression profile and regulatory factors during spermatogonial stem cell differentiation
}

\author{
Lei Zhang 1,2,3, Jiangjing Tang ${ }^{1,2,4}$, Christopher J Haines ${ }^{2}$, Huai Feng ${ }^{5}$, Liangxue Lai ${ }^{4}$, Xiaoming Teng ${ }^{1 *}$ \\ and Yibing $\operatorname{Han}^{1,2^{*}}$
}

\begin{abstract}
Background: It has been proven that c-kit is crucial for proliferation, migration, survival and maturation of spermatogenic cells. A periodic expression of $c-k i t$ is observed from primordial germ cells (PGCs) to spermatogenetic stem cells (SSCs), However, the expression profile of c-kit during the entire spermatogenesis process is still unclear. This study aims to reveal and compare c-kit expression profiles in the SSCs before and after the anticipated differentiation, as well as to examine its relationship with retinoic acid (RA) stimulation.

Results: We have found that there are more than 4 transcripts of c-kit expressed in the cell lines and in the testes. The transcripts can be divided into short and long categories. The long transcripts include the full-length canonical c-kit transcript and the $3^{\prime}$ end short transcript. Short transcripts include the $3.4 \mathrm{~kb}$ short transcript and several truncated transcripts (1.9-3.2 kb). In addition, the $3.4 \mathrm{~kb}$ transcript (starting from intron 9 and covering exons $10 \sim 21)$ is discovered to be specifically expressed in the spermatogonia. The extracellular domain of Kit is obtained in the spermatogonia stage, but the intracellular domain $(50 \mathrm{kDa})$ is constantly expressed in both SSCs and spermatogonia. The c-kit expression profiles in the testis and the spermatogonial stem cell lines vary after RA stimulation. The wave-like changes of the quantitative expression pattern of $c$-kit (increase initially and decrease afterwards) during the induction process are similar to that of the in vivo male germ cell development process.

Conclusions: There are dynamic transcription and translation changes of c-kit before and after SSCs' anticipated differentiation and most importantly, RA is a significant upstream regulatory factor for c-kit expression.
\end{abstract}

Keywords: $c$-kit, Expression profile, Spermatogonial stem cells, Differentiation, Regulatory factor

\section{Background}

Spermatogenesis starts from diploid spermatogonial stem cells (SSCs). The SSCs, also known as type A single $\left(\mathrm{A}_{\mathrm{s}}\right)$ $\mathrm{Spg}$, are located on the basement membrane of the seminiferous tubules. The $\mathrm{A}_{\mathrm{s}} \mathrm{Spg}$ can self-renew or produce the type A paired $\left(A_{p}\right)$ Spg. After successive divisions, $A_{p}$ Spg differentiates, forms chains of 4, 8 or 16 aligned Spg $\left(A_{a l}\right)$ and migrates along the basement membrane. $A_{a l}$ Spg differentiates into A1 Spg that further divides and differentiates into A2, A3, A4intermediates and B Spg, which undergoes meiosis after a final mitosis stage [1]. The "undifferentiated" $\left(A_{s}, A_{p}\right.$ and $\left.A_{a l}\right)$ and the "differentiating"

\footnotetext{
* Correspondence: xiaomingteng@hotmail.com; ybhan@yahoo.com ${ }^{1}$ Shanghai first maternity and infant health hospital, Tongji University, Shanghai, China

Department of Obstetrics and Gynaecology, Prince of Wales hospital, The Chinese University of Hong Kong, Hong Kong, China

Full list of author information is available at the end of the article
}

(A1, A2, A3, A4, intermediate and B) Spg differ in the expression profiles of $c-k t$ [2]. $c-k i t$ is allelic to the W locus on mouse chromosome 5 [3]. The 21-exon gene encodes for a $5150 \mathrm{bp}$ transcript, which is translated into a product of $145 \mathrm{kDa}$ protein with 979 amino acid residues. This product is known as Kit [4]. Kit transduces growth regulatory signals across the plasma membrane and has three main functional regions, the extracellular, the transmembrane and the intracellular domains [5,6]. Its transcription process is only activated after binding with Kitl expressed by the Sertoli cells. The Kit/Kitl pathway is considered to be crucial for the proliferation, migration, survival and maturation of the germ cells [7-18]. In spite of the 5.1 Kb full-length canonical transcript, two alternative mRNAs of $c$-kit, 3.2 and $2.3 \mathrm{~kb}$ in length, exist in the haploid cells of the mouse testis [19]. With an Open Reading Frame (ORF) that starts in the intron 16 of the mouse $c$-kit, an alternative spermatid-specific $c$-kit transcript contains all of the

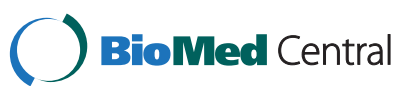


downstream exons (including 12 hydrophobic amino acids followed by the last 190 carboxyl terminal residues), encodes for Tr-Kit ( 30 kDa) [7,20,21]. The $30 \mathrm{kDa}$ Tr-Kit is found in the residual sperm cytoplasm and it has evident functions in the activation of oocyte during fertilization in mice $[21,22]$.

c-kit has been a marker for SSCs pluripotency lost and its expression continues until meiosis is initiated $[2,18]$. The expression of protein Kit in the male germ cells is contradictory to those of gene $c$-kit. In early studies, Kit expression is detected in type A (A1-A4), intermediate, type B spermatogonia, as well as preleptotene spermatocytes, but not in the undifferentiated spermatogonia $[2,18]$. More recent studies demonstrate that Kit is also expressed $A_{s}, A_{p r}$ and $A_{a l}$. Therefore, whether Kit is expressed in spermatogonia and whether Kit/Kitl activation is a prerequisite for differentiation or not remain to be a question [23-28]. Even though the inactivation of $c$-kit by its specific inhibitor Imatinib results in Spg selfrenewal impairment [29], both $\mathrm{Kit}^{-}$and $\mathrm{Kit}^{+}$spermatogonia have exhibited stem cell activities as evaluated by intraseminiferous transplantation $[1,24,30]$. The POU5F1 ${ }^{+} / \mathrm{Kit}^{+}$ subset of mouse SSCs can differentiate into several lines of somatic cells except for sperm cells [31].

We hypothesize that the expression profiles of $c$-kit in the male germ cells during spermatogenesis are dynamically changed before and after the expected differentiation, and these changes are important for their functional responses to the spermatogenesis-related genes. In this study, we have investigated the expression of $c$-kit in the immortal cell lines representing the SSCs, the differentiating spermatogonia and spermatocytes in hopes of understanding its natural expression patterns. We have also compared the $c$-kit expression patterns in those cell lines with their corresponding stage testes. The cell line c18-4 and 5 dpp mouse testes (before the initiation of spermatogonia differentiation) represent the undifferentiated spermatogonia. CRL-2053 and $10 \mathrm{dpp}$ mouse testes (after the initiation of spermatogonia differentiation) represent the differentiating spermatogonia. CRL-2196 cells represent primary spermatocytes. The $60 \mathrm{dpp}$ testes represent a mixture of the undifferentiated, the differentiating, the maturing and the matured germ cells.

RA, an active metabolite of vitamin A, is a vital signaling molecule for normal fetal development, pattern formation, cell proliferation, differentiation and apoptosis $[32,33]$. RA is considered to be crucial for germ cells to undergo meiosis in both male and female [34,35]. Testes of adult vitamin A-deficient mice/rat have seminiferous tubules that only contain Sertoli cells, type A spermatogonia and few preleptotene spermatocytes. With a reduced $c$-kit expression or without Stra8 expression, the type A spermatogonia will arrest before differentiation (before A1 stage spermatogonia) [36]. Administration of vitamin A to these animals results in a synchronized spermatogenesis emerging from type A spermatogonia and an enhanced expression of $c$-kit [37]. Therefore, RA is a key regulatory factor for $c$-kit expression.

\section{Methods \\ Cell lines and animals}

The c18-4 cell line represents the mouse SSCs [38]. CRL2053 (ATCC) is a type B spermatogonia cell line [39]. CRL-2196 (GC-2spd(ts), ATCC) is a spermatocyte cell line $[40,41]$. C57/BL6 mice at different ages were purchased from laboratory animal service center (LASEC), The Chinese University of Hong Kong. All procedures were approved by the Animal Research Ethics Committee of the University.

\section{Cell culture}

All cells were cultured in the Dubecco modified eagle medium/F12 (DMEM/F12, Invitrogen, Carlsbad, CA, USA) supplemented with $10 \%$ fetal bovine serum (FBS, Invitrogen, Carlsbad, CA, USA). A subcultivation ratio of 1:6 to 1:10 was applied. Media were renewed 1 to 2 times per week. The cells were frozen in complete growth medium supplemented with $5 \%(\mathrm{v} / \mathrm{v})$ DMSO and stored in liquid nitrogen.

\section{Mouse testes collection}

Mice at 5 days post partum (dpp), $10 \mathrm{dpp}$ and $60 \mathrm{dpp}$ were sacrificed by cervical dislocation. For RNA extraction, testes were washed twice with phosphate buffered saline (PBS) and then immersed in "RNA-later" stabilization reagent (Qiagen, Valencia, CA, USA). Before protein extraction, testes were washed twice with PBS, transported in iceboxes and stored in $-80^{\circ} \mathrm{C}$. Three batches of animals were used for each experiment.

\section{In vitro tissue culture and RA induction}

In vitro tissue culture was carried out according to the methods described by previous study [42]. Testes from $5 \mathrm{dpp}, 10 \mathrm{dpp}$ and $60 \mathrm{dpp}$ mice were detunicated, cut into small pieces per testis, placed on Millicell CM filters (Millipore, Bedford, MA, USA) floating on the surface of medium and covered with drops of medium (DMEM/F12 + 10\% FBS). RA (Sigma-Aldrich Co., Saint Louis, MO, USA) diluted in ethanol was added to the culture medium to make a final a concentration of $0.7 \mu \mathrm{M}$ or $2 \mu \mathrm{M}$. Tissues were harvested after 24 hours of RA treatment. Total RNA was isolated using the RNeasy mini kit (Qiagen, Valencia, CA, USA).

\section{In vitro cultured germ cells and RA induction}

For germ cell exclusive induction assay, $2 \times 10^{6}$ c18-4 or CRL-2063 cells were pre-seeded into T25 cell culture flasks separately (2 flasks each group) overnight before 
the treatment in full medium (DMEM/F12 + 10\% FBS). Induction media (DMEM/F12 +10\% FBS) with a final concentration of $2 \mu \mathrm{M}$ RA dissolved in ethanol were used in the treatment (induction) group. The same amount of ethanol without RA medium was set up as the control group. After 24 hours of induction, the induction media was removed, cells were washed with PBS twice, and cells were collected and stored at $-80^{\circ} \mathrm{C}$ until analysis. Three independent replications were carried out for each experiment.

\section{Methods for RNA preparation, electrophoresis and Northern blot}

Total RNA from cells and testes was isolated using the RNeasy mini kit (Qiagen, Valencia, CA, USA) following the manufacturer's instructions. Sizes of RNA were estimated by comparing with $2 \mu \mathrm{g}$ RNA Millennium size markers (Ambion, Austin, TX, USA) by measuring the distance from each band to the loading well.

DNA fragments corresponding to exons 10-12 and exons $18-20$ of the full-length $c$-kit transcript were obtained by PCR with $c$-kit specific primers using the $60 \mathrm{dpp}$ mouse testis cDNA as the template. Primers sequences are shown in Table 1. Amplified DNA fragments were inserted into the Topo-TA vector (Invitrogen, Carlsbad, CA, USA). The plasmids were then extracted by QIAprep spin miniprep kit (Qiagen, Valencia, CA, USA) and were sent to commercial company for sequencing.

RNA probes were prepared by MAXIscript kit (Ambion, Austin, TX, USA) following the manufacturer's instructions. mRNA-complementary (antisense) transcripts were synthesized in a $20 \mu \mathrm{l}$ in vitro transcription system containing $1 \mu \mathrm{g}$ DNA template, $2 \mu \mathrm{l} 10 \times$ transcription buffer, $1 \mu \mathrm{l} 10 \mathrm{mM}$ ATP, $1 \mu \mathrm{l} 10 \mathrm{mM}$ CTP, $1 \mu \mathrm{l} 10 \mathrm{mM} \mathrm{GTP}, 5 \mu \mathrm{l}$ $800 \mathrm{Ci} / \mathrm{mmol}[\alpha-32 \mathrm{P}]$ UTP at a concentration of $10 \mathrm{mCi} / \mathrm{mL}$ (Perkinelmer, San Jose, CA, USA) and $2 \mu \mathrm{l}$ T3 enzyme mix. After purification with NucAway Spin columns (Ambion, Austin, TX, USA), the RNA probes were hybridized with the blots with RNA samples in the ULTRAhyb ultrasensitive hybridization buffer (Ambion, Austin, TX, USA) at $68^{\circ} \mathrm{C}$ overnight. The same blot was stripped and re-probed with $\alpha^{32} \mathrm{P}$-labeled beta-actin RNA probe as internal control. Northern hybridization was performed twice with probes and membranes that were made independently. The sequences of PCR primers and RNA probes are shown in Table 1.

\section{Rapid amplification of CDNA ends (RACE), cloning and sequencing}

The number and size of $c$-kit mRNA expressed in mice cell lines and testis were determined by the Northern blot, the existence of these transcripts were further confirmed by RACE and sequencing. We used the BDSmarter RACE protocol from BD Biosciences Clontech
Table 1 PCR primers, real-time PCR primers and RNA probe sequence of mouse c-kit gene

\begin{tabular}{ll}
\hline Probe name & Probe sequence $\left(\mathbf{5}^{\prime} \boldsymbol{\rightarrow} \mathbf{3}^{\prime} \mathbf{)}\right.$ \\
\hline PCR primers & \\
Exons 10-12 & Sense $5^{\prime}$-TGGGGATCATTGTGATGGT-3' \\
& Anti-sense 5'-ATGGCAGCATCCGACTTAAT-3' \\
Exons 18-20 & Sense 5' - CCTCTGGGAGCTCTTCTCCT-3' \\
& Anti-sense 5'- GCTGTCCGAGATCTGCTTCT-3'
\end{tabular}

Real-time PCR primers

Exon 7-8

Exon 20-21

Exon 21+

AACGTTTACGT GAACACAAAACCAG

GCACCAAGCACATTTACTCCAACTT

CTGATATGTTGTCCAACTGTTGACA

Exons 10-12 probe (extracellular domain)

ATGGCAGCATCCGACTTAATCAAGCCA TATGCAGTGGCCTCAACGACC

TTCCCGAAGGCACCAGCTCCCAATGTC TITCCAAAACTCAGCCTGTTC

TGGGAAACTCCCATITGTGATCATAAGG AAGTTGCGTCGGGTCTATGT

AAACATAATTGTTTCCATTTATCTCCTCG ACAACCTTCCATTGTACTTC

ATACATGGGTTTCTGCAAATATTTGTAGG TGAGCAC CATCACAATG

ATCCCCAT

Exons 18-20 probe (intracellular domain)

GCTGTCCGAGATCTGCTTCTCAATAAGTT GGACAACCTGCTTGAATGT

TGGCCTITTCAAGGGGTCAGCGTCCCAG CAAGTCTTCATGAC

GTCATACATTTCGGCAGGCG CGTGCTCCGG GCTGACCATC

CGGAAGCCTTCCTTGATCATCTTGTAGAACTT GGAGTCGACCGGCATC

CCTGGGTAGGGGCTGCTTCCTAAGGAGAAG AGCTCCCAGAGG

Exons 10-12 probe hybridizes to $c$-kit extracellular domain coding area. Exons 18-20 probe hybridizes to c-kit intracellular domain coding area.

(Paloalto, CA, USA) in RACE analysis. The full-length cDNAs was made by joint action of the SMARTer II A Oligonucleotide and SMARTScribe Reverse Transcriptase (a variant of MMLV RT) in reverse transcription reactions. The first strand of cDNA synthesis was obtained from $1 \mu \mathrm{g}$ total RNA. PCR amplification was done with specific primers hit exons $10-12$ and exons $18-21$ on the fulllength $c$-kit transcript (Table 2) in conjunction with universal primers that were provided in the kit. Advantage 2 PCR kit (Clontech, Paloalto, CA, USA) was used for the $5^{\prime}$ and 3' PCR amplification. Nested PCR and touchdown PCR were used to safeguard the specificity of the amplification. Electrophoresis of the PCR products, bands cutting and gel extraction (QIAquick gel extraction kit; QIAGEN, Valencia, CA, USA) were performed. All of the clear RACE PCR product gel extractions were cloned to TA vector (TOPO TA cloning kit for sequencing, Invitrogen, 
Table 2 RACE primers

\begin{tabular}{|c|c|c|c|c|c|}
\hline Name & $5^{\prime}$ or $3^{\prime}$ & Sequence $\left(5^{\prime} \rightarrow 3^{\prime}\right)$ & $\begin{array}{l}\text { No. of } \\
\text { bases }\end{array}$ & $\begin{array}{l}\text { Exons } \\
\text { hitting }\end{array}$ & $\begin{array}{l}\text { Position on } \\
\text { NM_021099 }\end{array}$ \\
\hline e11 5' & $5^{\prime}$ & $\begin{array}{l}\text { CAGCCTGTTTCTGGG } \\
\text { AAACTCCCATTTG }\end{array}$ & 27 & Exon 11 & 1825-1798 \\
\hline e12 5' & $5^{\prime}$ & $\begin{array}{l}\text { GCAACTGTCATGGC } \\
\text { AGCATCCGACTT }\end{array}$ & 26 & Exon 12 & 1920-1895 \\
\hline e18 5' & $5^{\prime}$ & $\begin{array}{l}\text { TGCTCTCTGGTGCCA } \\
\text { TCCACTTCAC }\end{array}$ & 25 & Exon 18 & $2552-2756$ \\
\hline e20 5'A & $5^{\prime}$ & $\begin{array}{l}\text { GGTCAGCGTCCCAG } \\
\text { CAAGTCTTCAT }\end{array}$ & 25 & Exon 20 & $2786-2762$ \\
\hline e20 5'B & $5^{\prime}$ & $\begin{array}{l}\text { AAGGGGTCAGCGTC } \\
\text { CCAGCAAGTCT }\end{array}$ & 25 & Exon 20 & $2790-2766$ \\
\hline e20 5'C & $5^{\prime}$ & $\begin{array}{l}\text { TGCTTGGTGCTGTCC } \\
\text { GAGATCTGCT }\end{array}$ & 25 & Exon 20 & $2856-2832$ \\
\hline e21 5' & $5^{\prime}$ & $\begin{array}{l}\text { GGGGTTGCAGTTTG } \\
\text { CCAAGTTGGAG }\end{array}$ & 25 & Exon 21 & $2887-2863$ \\
\hline e10 3' & $3^{\prime}$ & $\begin{array}{l}\text { AAATCCAGGCCCAC } \\
\text { ACTCTGTTCACG }\end{array}$ & 26 & Exon 10 & $1602-1627$ \\
\hline e11 3' & $3^{\prime}$ & $\begin{array}{l}\text { TGGGAGTTTCCCAG } \\
\text { AAACAGGCTGAG }\end{array}$ & 26 & Exon 11 & 1802-1827 \\
\hline e18 3' & $3^{\prime}$ & $\begin{array}{l}\text { CCGTGAAGTGGATG } \\
\text { GCACCAGAGAG }\end{array}$ & 25 & Exon 18 & $2550-2574$ \\
\hline e19 3'A & $3^{\prime}$ & $\begin{array}{l}\text { AGGAAGCAGCCCCT } \\
\text { ACCCAGGGATG }\end{array}$ & 25 & Exon 19 & $2650-2674$ \\
\hline e19 3'B & $3^{\prime}$ & $\begin{array}{l}\text { GGGATGCCGGTCGA } \\
\text { CTCCAAGTCT }\end{array}$ & 25 & Exon 19 & $2669-2693$ \\
\hline e20 3'A & $3^{\prime}$ & $\begin{array}{l}\text { TGACCCCTTGAAAA } \\
\text { GGCCAACATTCA }\end{array}$ & 26 & Exon 20 & $2782-2807$ \\
\hline e20 3'B & $3^{\prime}$ & $\begin{array}{l}\text { GCAGATCTCGGACA } \\
\text { GCACCAAGCAC }\end{array}$ & 25 & Exon 20 & 2833-2857 \\
\hline
\end{tabular}

Requirement of a good gene specific primer for RACE: It should be $23-28 \mathrm{nt}$, has $50-70 \% \mathrm{GC}$ and $\mathrm{Tm}>70^{\circ} \mathrm{C}$, and does not complement to the $3^{\prime}$ of the Universal Primer Mix.

Carlsbad, CA, USA) and sent to commercial company for sequencing. 5' and 3' RACE results were combined to obtain the full-length $c$-kit transcripts sequence information.

\section{Quantitative real-time RT-PCR}

Total RNA $(2 \mu \mathrm{g})$ was treated with DNase I (Sigma, Saint Louis, USA) for 15 minutes at room temperature and then reversely transcribed by High Capacity cDNA Reverse Transcription Kit (Applied Biosystems, Foster City, CA, USA).

Real-time RT-PCR analysis of $c$-kit was performed with Taqman universal PCR master mix and Taqman gene expression assays on the ABI Prism 7900HT Real Time PCR System, according to the manufacturer's instructions (Applied Biosystems, Foster City, CA, USA). The relative expression level of each target gene was calculated by the comparative CT method and was normalized to glyceraldehyde 3-phosphate dehydrogenase (GAPDH) expression. Three $c$-kit gene-specific probes that hit different parts of the full-length transcript (exon 7-8, exon 20-21 and exon $21^{+}$) were used.
Real-time RT-PCR analysis for other genes were performed with Power SYBR PCR master mix and gene specific primers on the ABI Prism 7900HT Real Time PCR System, according to the manufacturer's instructions (Applied Biosystems, Foster City, CA, USA). The relative expression level of each target gene was calculated by the comparative CT method and was normalized to GAPDH expression. The primers of the candidate genes are list in Table 3.

Each RT-PCR analysis was repeated 3 times after GAPDH normalization.

\section{Western blot}

Cells and testis tissues were lysed on ice in RIPA buffer containing $1 \%$ freshly added protease inhibitors. Protein electrophoresis and gel bolting were performed with NuPAGE electrophoresis system (Invitrogen, Carlsbad, CA, USA) following the manufacturer's instructions. The blotted PCDF membranes were blocked with 5\% (wt/vol) non-fat dry milk (RT, 60 minutes) and probed for Kit at $4^{\circ} \mathrm{C}$ overnight, using either $1 \mu \mathrm{g} / \mathrm{ml}$ of a monoclonal antibody (rat anti-mouse; NOVUS, Littleton, CO, USA) directed against the extracellular domain of the Kit or a polyclonal antibody (rabbit anti-human, mouse, rat; NOVUS, Littleton, CO, USA) directed against the amino acid near S715 of the human Kit $(1 \mu \mathrm{g} / \mathrm{ml})$ followed by the HRP-conjugated secondary antibodies (Santa Cruz, Santa Cruz, CA, USA) staining.

Protein lysate from Kit expressed in human megakaryoblast cell lines (ATCC no. CRL-2021) was set up as positive control and protein lysate from Kit negative mouse myoblast cell line (ATCC no. CRL-1772) was set up as negative control. The same blot was stripped and re-probed with mouse beta-actin primary antibody (Santa Cruz, Santa Cruz, CA, USA) as internal control.

\section{Immunofluorescence staining of cells}

The cover slips with the cells were washed 3 times with PBS again and were incubated with 5\% normal goat serum (Santa Cruz, Santa Cruz, CA, USA) in PBS for

Table 3 Gene specific primers of the candidate genes

\begin{tabular}{lll}
\hline Name & Forward & Reverse \\
\hline BMP4 & TTCCTGGTAACCGAATGCTGA & CCTGAATCTCGGCGACTTTT \\
Cyp26b1 & GCAAGATCCTACTGGGCGAAC & TTGGGCAGGTAGCTCTCAAGT \\
DAZL & GTCCTTACATGTACCATTC & GACTCCAACAAAACAGC \\
& TGTGAC & AGACAA \\
EGR 3 & AGCTGAACTGGGCTGTGTCT & AATGGGGAGTGGGTATGTGA \\
Kitl & TCTGCGGGAATCCTGTGACT & TGGAAGATTGCCACCAGTT \\
PLZF & GCAAGAACAGCGTCAAGACA & TGGGATCACGTGAAGCTATG \\
RARa & TCCGAAGAGATAGTACCCAGC & AAAGCAAGGCTTGTAGATGCG \\
Stra8 & GTTTCCTGCGTGTTCCACAAG & CACCCGAGGCTCAAGCTTC \\
\hline
\end{tabular}


30 minutes before being incubated with the primary antibody overnight at $4^{\circ} \mathrm{C}$. The cells were then incubated with the secondary antibody and mounted with UltraCruz ${ }^{\mathrm{TM}}$ Mounting Medium with DAPI (SantaCruz, Santa Cruz, CA, USA). The following antibodies were used in this study: the FITC monoclonal rat-anti-mouse Kit extracellular domain (1:200, 105805, BioLegend, San Diego, CA, USA), the monoclonal rat-anti-mouse Kit extracellular domain (1:200, NBP1-43359, NOVUS, Littleton, CO, USA), the monoclonal rat-anti-mouse Kit extracellular domain (1:100, KJ-14, Santa Cruz, Santa Cruz, CA, USA); the polyclonal rabbit-anti-human/mouse/rat Kit intracellular domain (1:200, NBP1-19865, NOVUS, Littleton, CO, USA), the polyclonal goat-anti-mouse Kit C-terminus (1:100, M14, Santa Cruz, USA) and the polyclonal rabbit-anti-human/mouse Kit C-terminus (1:100, C19, Santa Cruz, Santa Cruz, CA, USA). The secondary antibodies used in this study included: the Alexa 488-conjugated goat-anti-rat IgG (1:500; Invitrogen, Carlsbad, CA, USA); the Alexa 594-conjugated goat-anti-rabbit IgG (1:500; Invitrogen, Carlsbad, CA, USA) and the Texas red-conjugated donkey-anti-goat IgG (1:100; Santa Cruz, Santa Cruz, CA, USA).

\section{Statistical analysis}

Statistical analysis was performed by unpaired two-tail student $t$ test using SPSS software (Version 17.0). All experiments were performed for at least three independent times and a $\mathrm{P}$ value of less than 0.05 was considered statistically significant.

\section{Results}

Transcription of c-kit in cell lines and testes

Northern blots revealed at least 4 transcripts in the cells and testes (Figure 1B and C). Even more $c$-kit transcripts expressed in c18-4, CRL-2053 and $5 \mathrm{dpp}, 10 \mathrm{dpp}$ and 60 dpp testes were assayed by RACE (Figure 2A, B, C, D). The $1.5 \mathrm{~kb}$ transcript expressed in the c18-4 cells was not shown by RACE (Figure $1 \mathrm{C}$ ). Four representative transcripts (Type A, B, C and D) were illustrated in Figure 3 and a multiple blast of their sequences was shown in Additional file 1. Quantitative expression discrepancies (either in the $5^{\prime}$ end or in the $3^{\prime}$ end) of $c$-kit among the cell lines and testes of different stages existed. Multiple blast assays demonstrated that exons 17-21 region was highly conserved in the $c$-kit transcripts. The four representative transcripts included the full-length canonical transcript (transcript A, $5.1 \mathrm{~kb}$, expressed in 10 and 60 dpp testes), the 3 ' end short transcript (transcript B, $3.9 \mathrm{~kb}$, expressed in c18-4, CRL-2053, 5 and $10 \mathrm{dpp}$ testes), the short transcript (transcript $\mathrm{C}, 3.4 \mathrm{~kb}$, expressed in CRL-2053) and the truncated transcripts (transcripts D, 1.9-3.2 kb, no expression detected by Northern blot analysis) respectively (Figure 3).

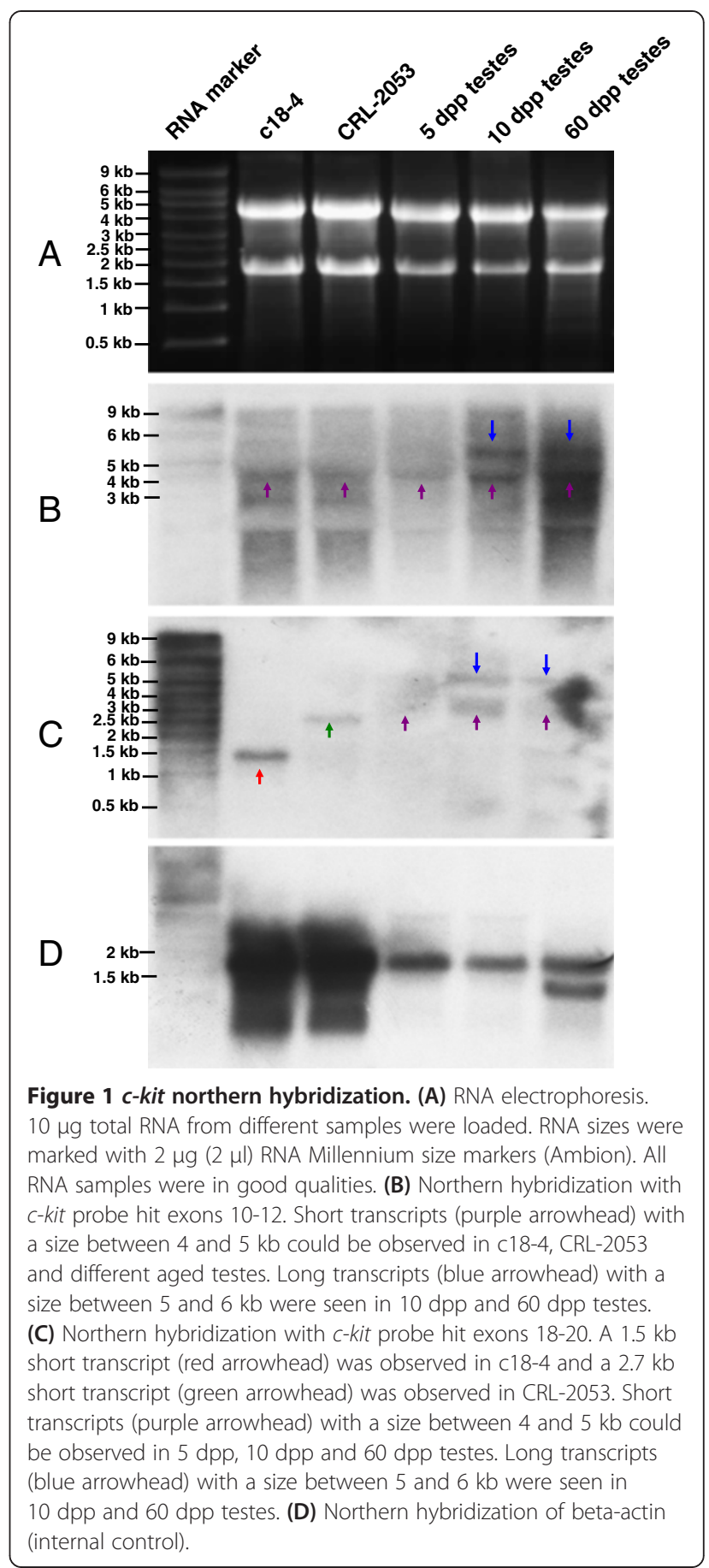

Quantitative analysis of different transcript expressions in testes and germ cell lines

Three sets of specific primers for RT-PCR were designed to detect $c$-kit transcripts (e7-8, e20-21 and e $21^{+}$as indicated by triangles in Figure 3 ). Products from the e7-8 primers represented the long transcripts (transcripts $A+B$ ). Products from the e20-21primers represented the total transcripts (transcripts $\mathrm{A}+\mathrm{B}+\mathrm{C}+\mathrm{D}$ ). The ratio of the long transcripts could be calculated as (e7-8/e20-21) $\times 100 \%$. 

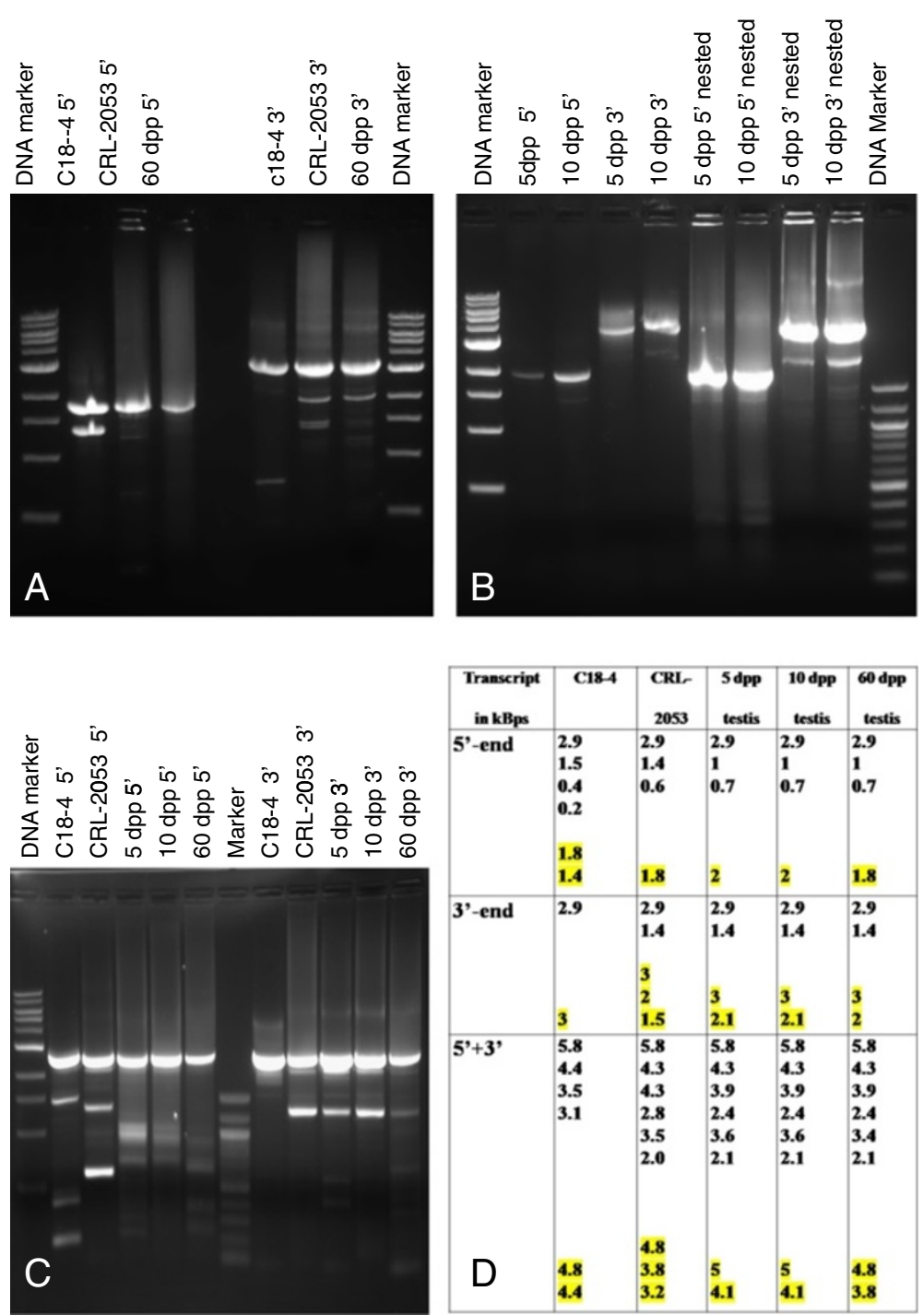

Figure 2 RACE PCR products gel electrophoresis. (A) $5^{\prime}$ and $3^{\prime}$ RACE with primer sets hit exons 10-12. c18-4 had two $5^{\prime}$ ends (1.8 kb and $1.4 \mathrm{~kb})$. CRL-2053 and $60 \mathrm{dpp}$ testes had one $5^{\prime}$ end (1.8 kb). c18-4 had one $3 \mathrm{~kb} 3^{\prime}$ end (3 kb). CRL-2053 and $60 \mathrm{dpp}$ testes had two $3^{\prime}$ end ( $3 \mathrm{~kb}$ and $1.8 \mathrm{~kb}$ ). (B) 5' and $3^{\prime}$ RACE with primer sets hit exons 10-12. $5 \mathrm{dpp}$ and $10 \mathrm{dpp}$ testis had one $5^{\prime}$ ends (2 kb). $5 \mathrm{dpp}$ and $10 \mathrm{dpp}$ testes had two $3^{\prime}$ end ( $3 \mathrm{~kb}$ and $2.1 \mathrm{~kb}$ ). CRL-2053 and $60 \mathrm{dpp}$ testes had two $3^{\prime}$ end ( $3 \mathrm{~kb}$ and $\left.1.8 \mathrm{~kb}\right)$. (C) $5^{\prime}$ and $3^{\prime}$ RACE with primer sets hit exons 18-21. c18-4 had two $5^{\prime}$ ends (2.9 kb and $1.5 \mathrm{~kb}$ ). CRL-2053 had three $5^{\prime}$ ends ( $2.9 \mathrm{~kb}, 1.4 \mathrm{~kb}$ and $1.6 \mathrm{~kb}$ ). $5 \mathrm{dpp}, 10 \mathrm{dpp}$ and $60 \mathrm{dpp}$ testes had the same one $5^{\prime}$ end (2.9 kb); c18-4 had one $3^{\prime}$ end (2.9 kb). CRL-2053 $5 \mathrm{dpp}$ and $10 \mathrm{dpp}$ and $60 \mathrm{dpp}$ testes had two $3^{\prime}$ end (3 kb and $\left.1.8 \mathrm{~kb}\right)$.

(D) Summary of c-kit RACE PCR fragments from cell lines and testis.

The ratio of the short transcripts (Transcript $\mathrm{C}+\mathrm{D}$ ) was consequently $\left(1\right.$-ratio $\left.{ }_{\text {long transcripts }}\right) \times 100 \%$. Those produced by $\mathrm{e} 21^{+}$primers represented all transcripts with a long $3^{\prime}$ end except for transcript B (Transcripts $\mathrm{A}+\mathrm{C}+\mathrm{D}$ ). The ratio of the long $3^{\prime}$ UTR transcripts was $\left(\mathrm{e} 21^{+} / \mathrm{e} 20-\right.$ $21) \times 100 \%$. The ratio of the short $3^{\prime}$ UTR transcripts was (1-ratiolong $3^{\prime}$ UTR transcripts $) \times 100 \%$.

From $5 \mathrm{dpp}$ to $10 \mathrm{dpp}$, expressions of both transcripts $A+B$ and transcripts $C+D$ increased significantly (Figure 4A, B). The ratios of long and short transcripts remained constant $(22.47 \%$ in $5 \mathrm{dpp}$ and $22.45 \%$ in $10 \mathrm{dpp}$, Figure $4 \mathrm{~B})$. The ratio of long 3 ' transcripts jumped from $2.8 \%$ to $4.01 \%$ (Figure $4 \mathrm{C}$ ). From $10 \mathrm{dpp}$ to $60 \mathrm{dpp}$, transcripts $\mathrm{A}+\mathrm{B}+\mathrm{C}+\mathrm{D}$ increased moderately but transcripts $\mathrm{A}+\mathrm{C}+\mathrm{D}$ decreased. Hence, it can be deduced that transcript $B$ must have been enhanced significantly (Figure 4A). Consequently, since the relative amount of transcripts $\mathrm{A}+\mathrm{B}$ did not change, the quantity of transcript A must have declined dramatically. The ratio of short transcripts progressed from $22.45 \%$ in $10 \mathrm{dpp}$ to $54.91 \%$ in $60 \mathrm{dpp}$ (Figure 4B). Long $3^{\prime}$ transcripts dropped from $4.01 \%$ (10 dpp) to $0.60 \%$ (60 dpp) (Figure 4C).

Primers e $21^{+}$did not detect any bands in all three types of cell lines. As a result, all transcripts in these cell lines 


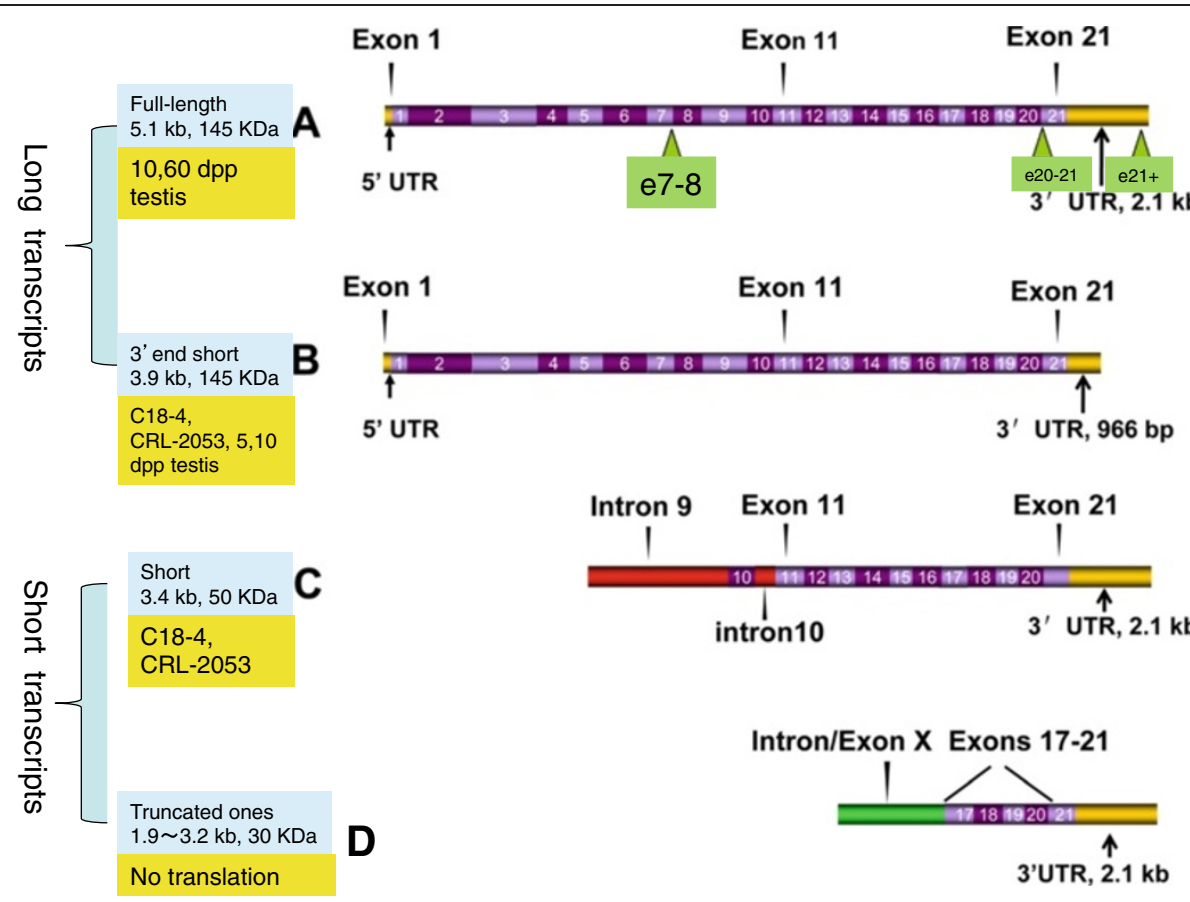

Figure 3 c-kit transcripts before and after differentiation of SSCs. (A) Full-length transcript. This transcript was composed of 21 exons and with a size about $5.2 \mathrm{~kb}$. A $2.1 \mathrm{~kb} 3^{\prime}$ UTR region located at exon 21 of this transcript and it was expressed by SSCs before and after differentiation. Green triangles on this figure represented 3 groups of c-kit primers that hit exons 7-8, exons 20-21 and exon 21 respectively. (B) Short 3' UTR transcript (4 kb). This transcript was composed of 21 exons with 966 bp long 3' UTR. (C) Short transcript (2.7 kb) started from intron 9 of the fulllength transcript. (D) The truncated transcript (1.5 kb). It represented a group of transcripts that started from different intron or exon of $c-k i t$ gene, the Intron/Exon X means the beginning of these transcripts. We found some of these transcripts started from exon 13 , exon 15 and exon 17 of the c-kit gene respectively. All these truncated transcripts we found containing a conserved domain from exon 17 to exon 21.

lacked of the 3' UTR ends. The relative quantity of transcript A was equivalent with transcript B in the cell lines. The expression of type $A+B$ multiplied significantly in CRL-2053 (about 20 folds of that in c18-4) and then diminished (about 5 folds of that in c18-4) in CRL-2196 (Figure $5 \mathrm{~A}$ ). The ratio of type $\mathrm{A}+\mathrm{B}$ transcripts was $65 \%$, 92.9\% and 56.4\% in c-18-4, CRL-2053 and CRL-2196 respectively (Figure $5 \mathrm{~B}$ ).

Translation of c-kit in the testes and male germ cell lines It was shown that full-length Kit (145 KDa) was expressed in CRL-2053 cells and testes except in c18-4 cells (Figure 6A). With an anti-intracellular antibody, a 50 KDa Kit was expressed in the c18-4, CRL-2053 and all testes (Figure 6B). From $5 \mathrm{dpp}$ to $60 \mathrm{dpp}$, the $145 \mathrm{KDa}$ Kit increased, but the $50 \mathrm{KDa}$ Kit remained homogenous in the testes (Figure 6). Both the c18-4 and CRL-2053 cells expressed the intracellular domain of Kit (nuclear region) (Figure 7B and D). Unlike the CRL-2053 cells, the c18-4 cells did not express the extracelluar domain (membrane region) (Figure $7 \mathrm{~A})$. In the $5 \mathrm{ddp}$ testes, expression of the extracellular domain was very minimal in the germ cells (Figure 8A). In the $10 \mathrm{dpp}$ testes, a portion of the germ cells adjacent to the basement membrane of the seminiferous tubules began to express the membrane domain
(Figure 8B). In the $60 \mathrm{dpp}$ testes, some spermatogonia and spermatocytes were tested positive for membrane domain (Figure 8C). In contrast, the nuclear domain was expressed in all stages ( $5 \mathrm{dpp}, 10 \mathrm{dpp}$ and $60 \mathrm{dpp}$ ) in the spermatogonia, spermatocyte and spermatids, but not in the mature spermatozoon (Figure 8D, E and F). Leydig cells highly expressed the nuclear domain of Kit in the 60 dpp testes (Figure 8F).

\section{Expression changes of c-kit and other differentiation-} related genes in the testes after RA stimulation $5 \mathrm{dpp}, 10 \mathrm{dpp}$ and $60 \mathrm{dpp}$ mouse testes were treated with either $0.7 \mu \mathrm{M}$ or $2 \mu \mathrm{M}$ RA in vitro for $24 \mathrm{~h}$. Quantitative expression of $c$-kit and SSCs differentiation related genes were determined by Real-time PCR using three pairs of primers (e7-8, e20-21 and $\mathrm{e} 21^{+}$as indicated by arrow heads in Figure 3 ). The total $c$-kit mRNA level increased following the RA treatment and exhibited a concentration-dependent pattern in $5 \mathrm{dpp}$ and $10 \mathrm{dpp}$ testes (Figure 9A, C). After RA stimulation, the $60 \mathrm{dpp}$ testes did not display concentration-dependent increases any more (Figure 9E). In $5 \mathrm{dpp}$ and $10 \mathrm{dpp}$ testes, expressions of $C y p 26 b 1$ and Stra 8 were significantly upregulated (Figure 9B, D). Expressions of Dazl and Kitl were enhanced moderately in $5 \mathrm{dpp}$ and $60 \mathrm{dpp}$ testes 


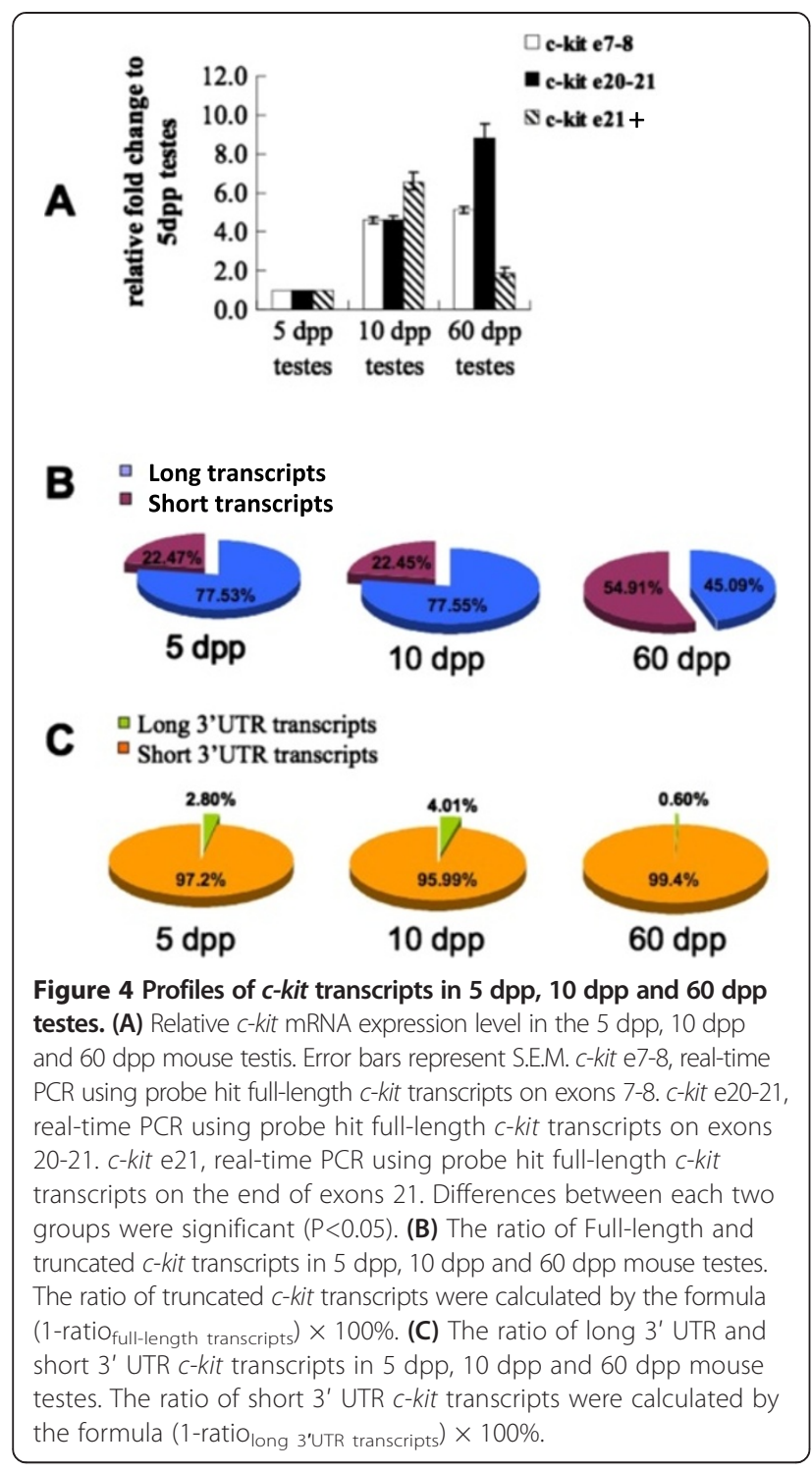

(Figure 9B, F). Bmp4 had a different response to RA treatment in testes of different ages (Figure 9B, D, F). The effects of RA on the expressions of Bmp4, Cyp26b1 and Stra 8 were more significant in the $5 \mathrm{dpp}$ testes than that in the 10 dpp testes. Expressions of RAR $\alpha$ and Egr3 were not altered in either stage (Figure 9B, D, F).

\section{Expression dynamics of $c$-kit and differentiation-related} genes in germ cell lines after RA stimulation

$c$-kit and other differentiation-related genes changes were analyzed in C18-4 and CRL-2053 cells after RA treatment ( $2 \mu \mathrm{M}$ RA for 24 hours). Unlike in the testes, the expressions of all transcripts declined in the c18-4 cells after RA stimulation (Figure 10A). In CRL-2053 cells, the amount of the long transcripts (e7-8 in Figure 10B) declined to about $50 \%$ but the quantity of total transcripts (e20-21 in Figure 10B) escalated to approximately 2 folds,

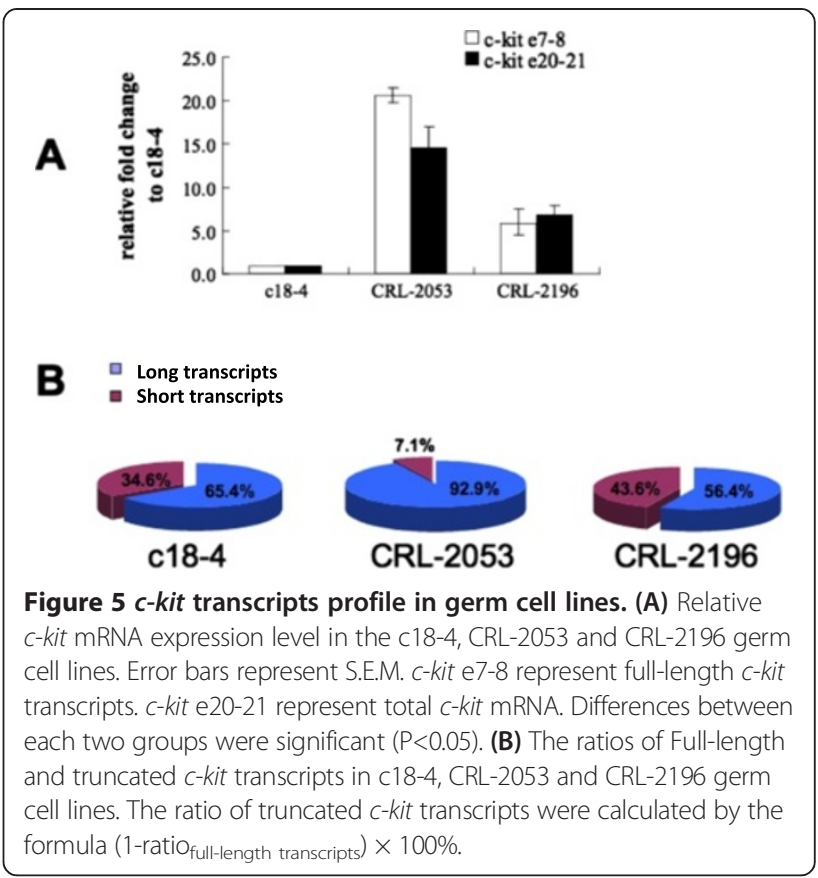

indicating that the short transcripts must have increased even more significantly (Figure 10B). Expressions of Cyp26b1 and Stra 8 increased significantly in both c18-4 and CRL-2053 cells $(\mathrm{P}<0.01)$ (Figure 10C, 10D). The two germ cell marker genes, Dazl and Pou5f1 had distinctive responses to RA. Dazl was boosted in $5 \mathrm{dpp}$ and $60 \mathrm{dpp}$ testis (Figure 9B, F), but not in either cell lines (Figure 10C, D). Pou5f1 diminished in c18-4 cells but did

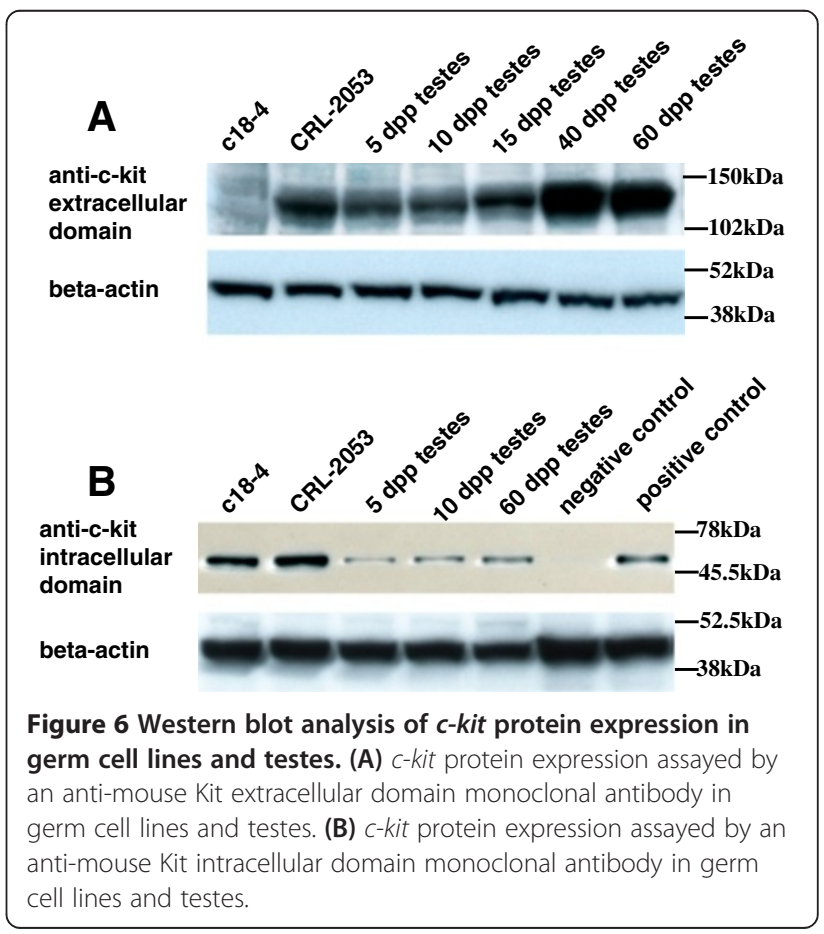




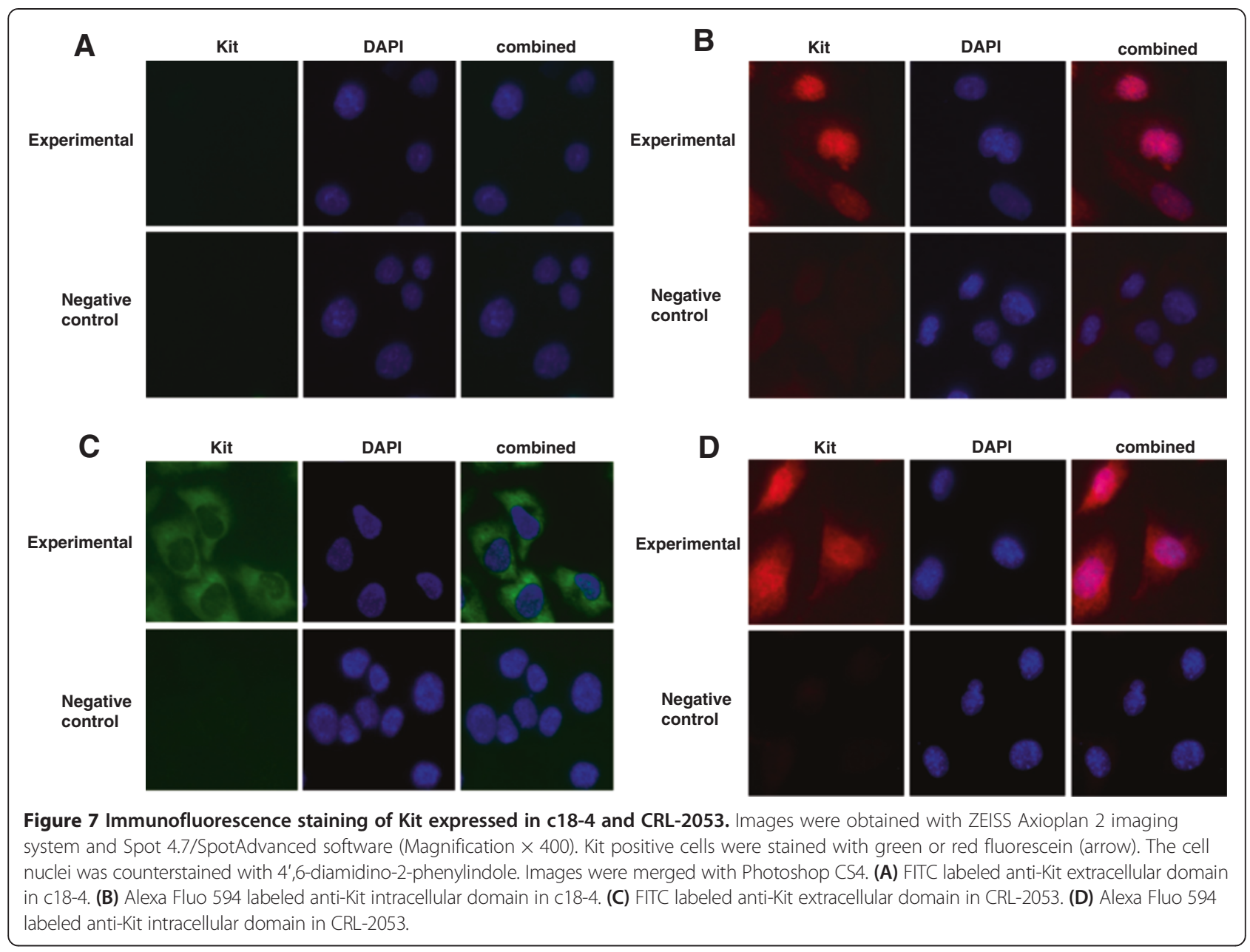

not change in CRL-2053 cells (Figure 10C and D). Egr3 (an early growth response gene) was suppressed in c18-4 and CRL-2053 cells (Figure 10C, 10D), but it was not altered in the testes (Figure 9B, D, F). Rara (an RA receptor gene) did not respond to RA stimulation.

\section{Discussion}

\section{A. c-kit transcripts during spermatogenesis}

In addition of the conventional full-length $c$-kit and Tr-kit discovered, we also found more than 3c-kit mRNA transcripts in the SSCs and spermatogonia. CRL-2053 had the highest amount of transcript A (Figure 5A). Though its quantity increased, the percentages of Transcript A declined in CRL-2196 and 60 dpp testes when compared with that in c18-4 cells and testes at $5 \mathrm{dpp}$ (Figure 4A, B, Figure 5A, B). The $145 \mathrm{KDa}$ Kit was also absent in c18-4 cells (Figure 6A). On this basis, acquisition of this transcript marked the start of the transition from SSCs to spermatogonia. The percentage of this transcript decreased in CRL-2196 cells and 60 dpp testes. This was caused by the emergence of new short transcripts, which were important for later stage spermatogenesis.
Expression of transcript B was the highest in the $10 \mathrm{dpp}$ testis (Figure 4A). The $3.9 \mathrm{~kb}$ short 3' UTR transcript was composed of 21 exons, identical to the full-length transcript. The only difference was that the $3.9 \mathrm{~kb}$ short 3' UTR transcript had a $1.2 \mathrm{~kb}$ shorter 3' UTR than the fulllength transcript. Combining its abundance in the testes (95.9\% 99.4\%, Figure 4C) with the strong positive staining of Leydig cells in the $60 \mathrm{dpp}$ testes (Figure 8F), it could be inferred that this transcript might be a somatic form. Functions of 3' UTR included supplying binding sites for microRNAs and post-transcriptional regulation. Absence of the 3' end UTR in all transcripts in the immortal germ cells (Figure 5A) indicated that the 3' UTR modification was lost during immortalization and it might be controlled by testicular somatic factors.

Transcript $\mathrm{C}$, encoding the $50 \mathrm{KDa} \mathrm{Kit}$, was stably expressed in the testes (Figure 6B). The percentage of the short transcripts (Transcript $\mathrm{C}+\mathrm{D}$ ) was the highest in the $60 \mathrm{dpp}$ testes (54.91\%) (Figure 4B) and CRL-2196 (43.6\%) (Figure 5B). Consequently, these transcripts might have significant roles in later stage spermatogenesis beginning from spermatocytes. Multiple sequence 


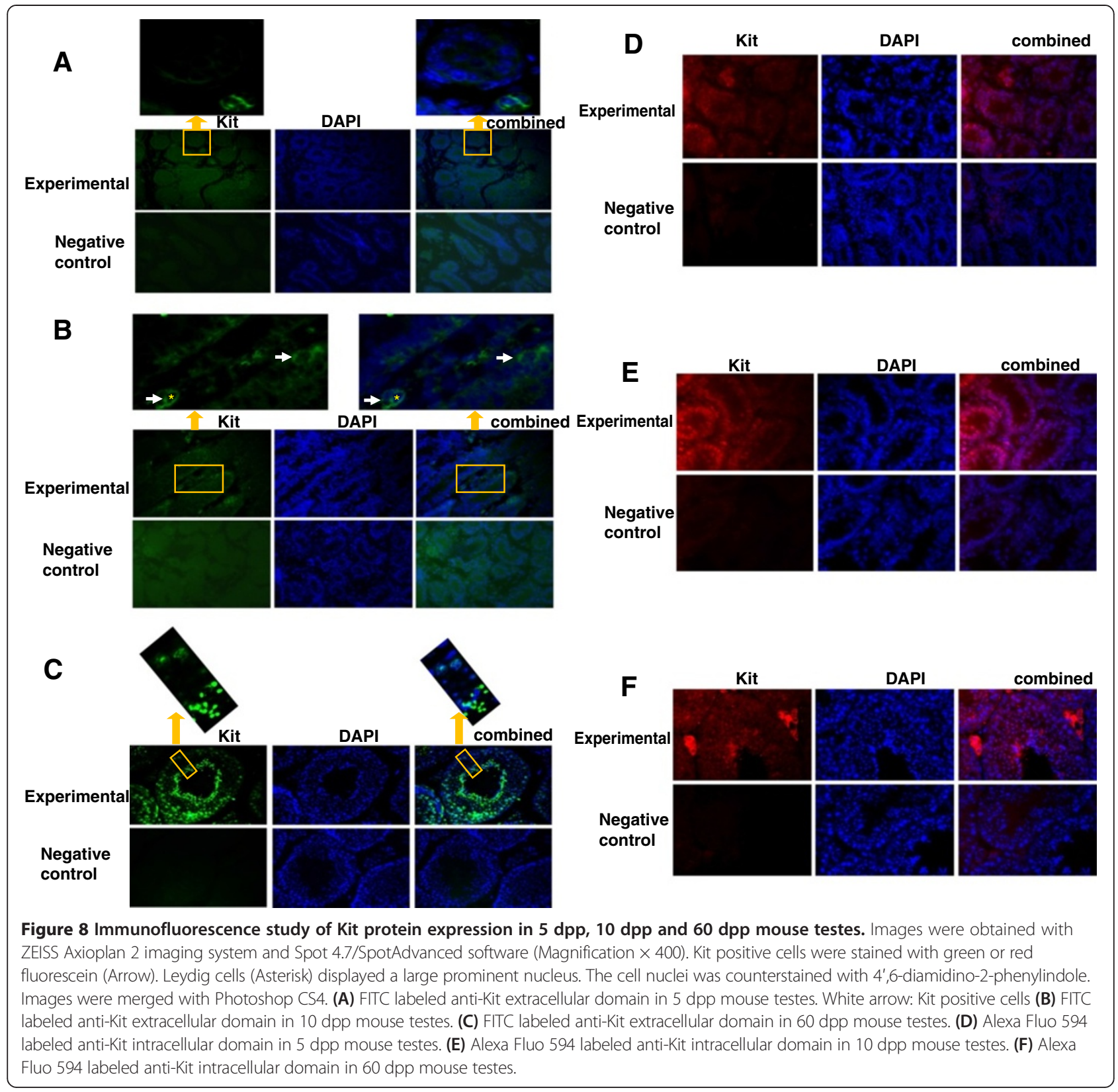

alignment of $c$-kit tranascripts was shown in Additional file 1.

\section{B. Kit profile during spermatogenesis}

Two forms of Kit were discovered in this study: the $145 \mathrm{kDa}$ and $50 \mathrm{kDa}$ Kit. The $145 \mathrm{kDa}$ Kit was located in the cytoplasm/membrane domain in CRL-2053 cells (Figure 7C) but not in c18-4 cells. Its expression escalated accordingly in the $5 \mathrm{dpp}, 10 \mathrm{dpp}, 15 \mathrm{dpp}, 40 \mathrm{dpp}$ and $60 \mathrm{dpp}$ testes (Figure 6A). Unlike the $145 \mathrm{kDa}$ fulllength Kit, the $50 \mathrm{kDa}$ Kit, possibly the product of transcript C, was expressed in both nuclear and cytoplasm/ membrane domains in CRL-2053 cells (Figure 6). The
$50 \mathrm{kDa}$ Kit was stably expressed in the testes (Figure 6B). Therefore, the $145 \mathrm{kDa}$ was indeed the marker for spermatogonia [43]. We highlighted here that its location shifted from the nucleus to the cytoplasm and then to the membrane domain. This might be vital for the initiation of spermatogenesis in SSCs. Expression of the extracellular full-length Kit on membranes, not in the nucleus or in the cytoplasm, endorsed the cells the ability to correspond with Kitl signals. Hence, this expression played important roles in differentiation initiation. We also demonstrated here that SSCs did not have fulllength transcript (transcript A), nor the full-length Kit $(145 \mathrm{kDa})$, which agreed with other studies indicating 

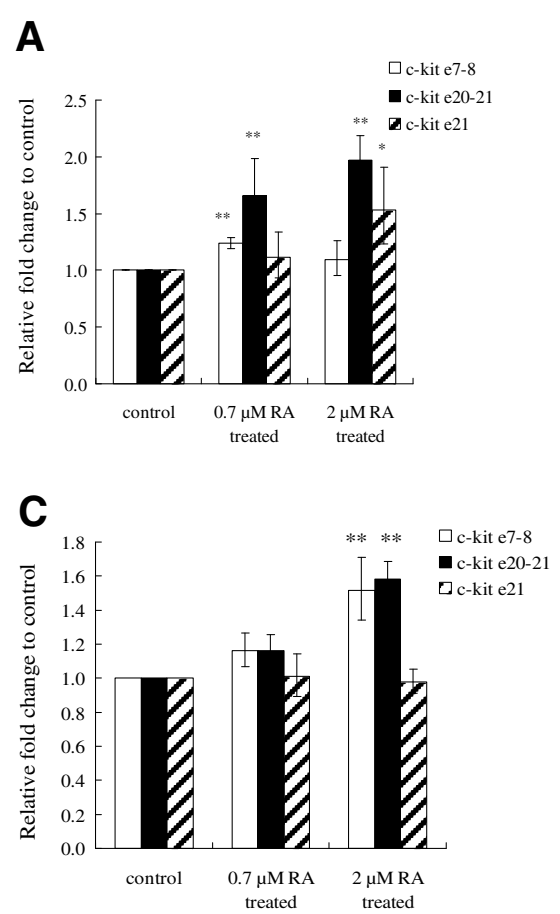

$\mathbf{E}$

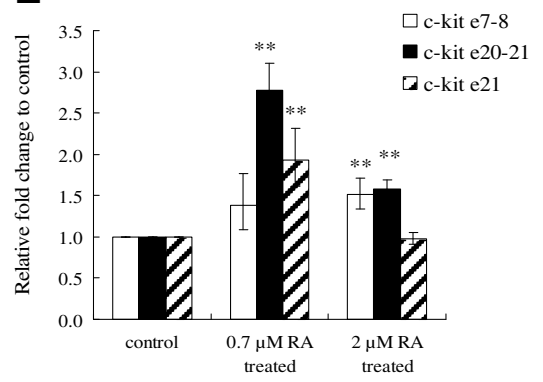

B
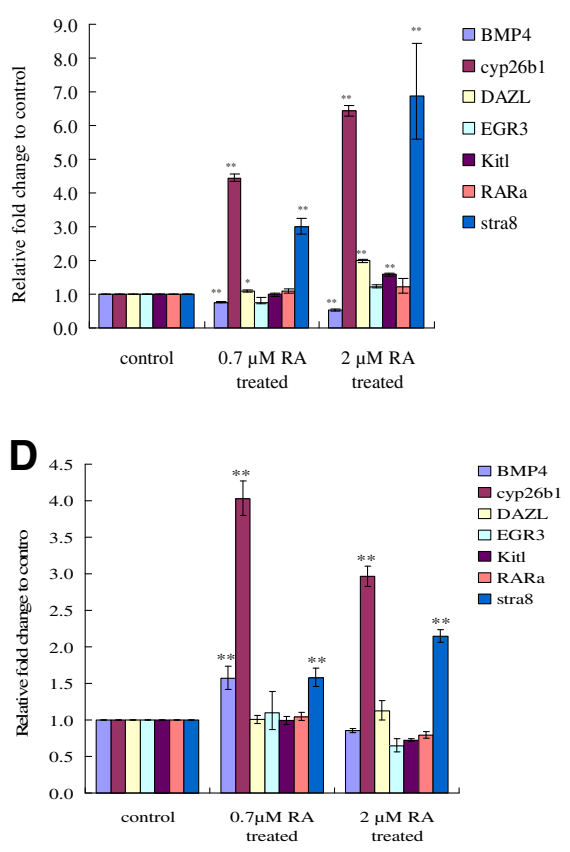

$\mathbf{F}$

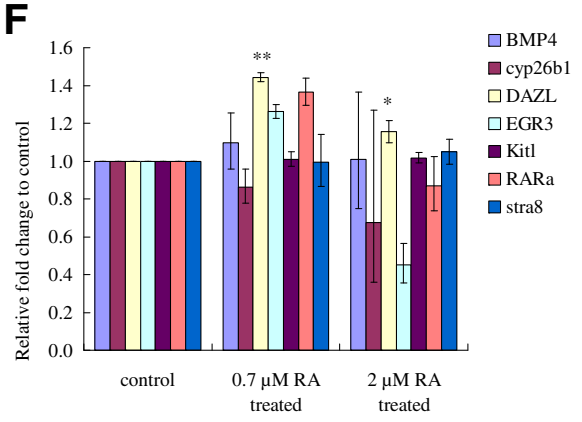

Figure 9 Expression of c-kit and other germ cell differentiation-related genes in the $5 \mathrm{dpp}, 10 \mathrm{dpp}$ and 60 dpp mouse testes stimulated by RA. $5 \mathrm{dpp}, 10 \mathrm{dpp}$ and $60 \mathrm{dpp}$ testes were treated with $2 \mu \mathrm{M}$ RA diluted in ethanol for $24 \mathrm{~h}$ in vitro. Testes treated with the same concentration of ethanol without RA were the control group. Realtime PCR was carried out for quantitative determination of the expression of c-kit and its potential regulatory genes (BMP4, Cyp26b1, DAZL, EGR3, Kitl, RARa and Stra8). Values of the vertical axis represented the expression fold change comparing with the control group. The results were normalized to GAPDH values. Error bars represent the S.E.M. Values with ** represented a significance with a $\mathrm{P}<0.01$ whereas values with * represented a significance with a $\mathrm{P}<0.05$ comparing with the control group. (A) c-kit expression in the $5 \mathrm{dpp}$ testes. (B) Expression of germ cell differentiation-related genes in the $5 \mathrm{dpp}$ testes. (C) c-kit expression in the $10 \mathrm{dpp}$ testes. (D) Expression of germ cell differentiation-related genes in the $10 \mathrm{dpp}$ testes. (E) c-kit expression in the $60 \mathrm{dpp}$ testes. (F) Expression of germ cell differentiation-related genes in the 60 dpp testes.

that the activation of the Kit/Kitl signaling pathway was not required for SSCs' self-renewal [23,24]. Kit was initially expressed in the nucleus, and then ventured out to the cytoplasm and then to the membrane domain when SSCs became spermatogonia. ORF finder comparison of the c-kit putative proteins sequences were shown in Additional file 2.

\section{C. $\mathrm{RA}$ responses in germ cells and testes}

Some studies showed that RA directly acts on spermatogenic cells by stimulating Stra 8 and c-kit gene expression, whereas some studies testified that exogenous RA could not stimulate $c$-kit expression $[16,42,44]$. We demonstrated that RA enhanced $c$-kit expression (Figure 9A, $\mathrm{C}$ and E) in testes. Stra 8 (gene stimulated by RA) was also significantly amplified in both cell lines and $5 \mathrm{dpp} / 10 \mathrm{dpp}$ testes (Figure 9B, D). However, the expression pattern of $c$-kit in the cell lines was different from that in the testes (Figure 10 vs Figure 9). Both long and short transcripts were reduced in c18-4 cells after RA stimulation (Figure 10A). On the other hand, the long transcripts were reduced whereas the short transcripts were promoted in CRL-2053 cells (Figure 10B). We concluded that RA indirectly impacted upon c-kit expression in 
A

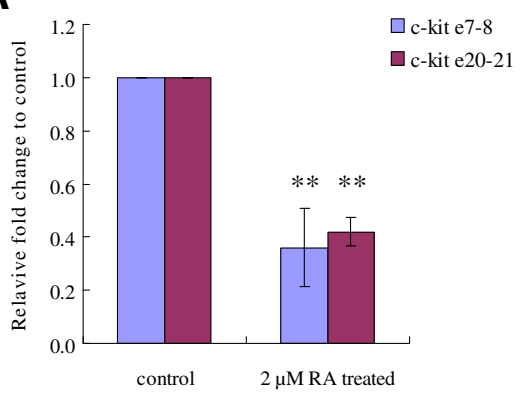

C

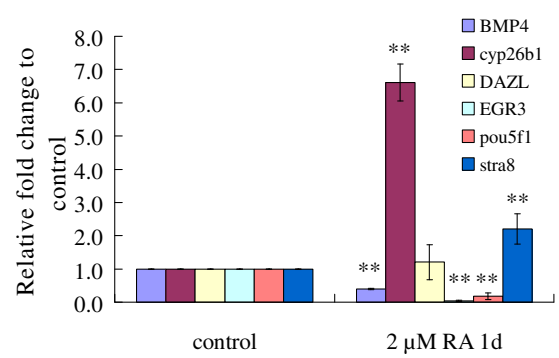

B

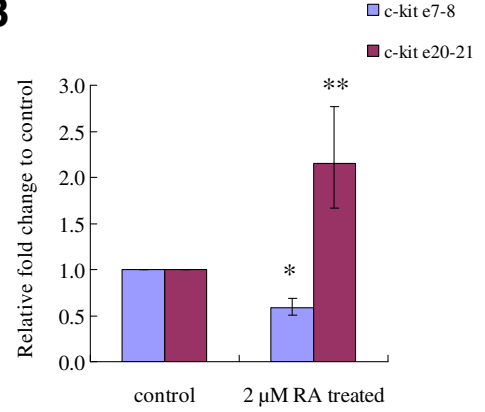

D

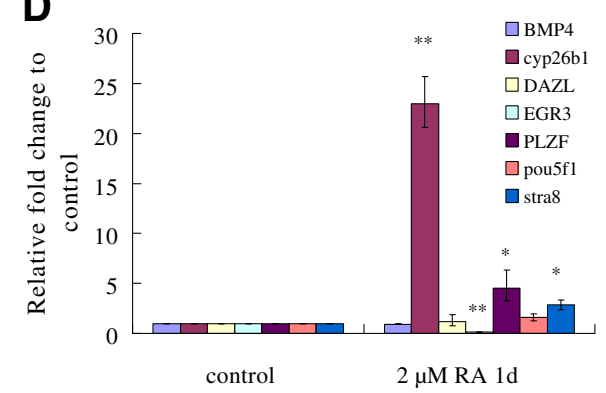

Figure 10 Expression of $c$-kit and other germ cell differentiation-related genes in the c18-4 and CRL-2053 cells stimulated by RA. The c18-4 and CRL-2053 cells were treated with $2 \mu \mathrm{M}$ RA diluted in ethanol for $24 \mathrm{~h}$ in vitro. Cells treated with the same concentration of ethanol without RA were the control group. Realtime PCR was carried out for quantitative determination of the expression of c-kit and its potential regulatory genes (Bmp4, Cyp26b1, Dazl, Egr3, Pou5f1 and Stra8). Values of the vertical axis represented the expression fold change comparing with the control group. The results were normalized to GAPDH values. Error bars represent the S.E.M. Values with ** represented a significance with a $P<0.01$ whereas values with * represented a significance with a $P<0.05$ comparing with the control group. (A) $c-k i t$ expression in the $c-18-4$ cells. (B) c-kit expression in the CRL-2053 cells. (C) Expression of germ cell differentiation-related genes in the c18-4 cells. (D) Expression of germ cell differentiation-related genes in the CRL-2053 cells.

male germ cells, while some unknown factors from the testes somatic cells might be involved. It agreed with previous works that RA indirectly controlled the timing of meiosis by juxtacrine of Sertoli cells [45].

Suppression of Bmp4 by RA was obvious. RA reduced Bmp4 (a SSCs pluripotential maintenance gene) expression in $5 \mathrm{dpp}$ testes (Figure 9B) and did not alter Bmp4 expression in $10 \mathrm{dpp}$ and $60 \mathrm{dpp}$ testes (Figure 9D, F). $B M P 4$ was also reduced in c18-4 cells after RA stimulation (Figure 10C). Excessive exogenous RA would push SSCs into abnormal differentiation and finally apoptosis [16]. Our results validified that after 24 hours of $2 \mu \mathrm{M}$ RA treatment, expression of Cyp $26 b 1$ (a RA degradation gene) was stimulated. This would degrade excessive RA into the inactive form in both cell lines and testes (Figure 9B, C, Figure 10C, D). Cyp26b1 was not altered in $60 \mathrm{dpp}$ testes (Figure 9F). The increase of the protective gene also varied in CRL-2053 cells $(\sim 20$ folds increase of Cyp26b1) and in c18-4 cells ( 6 folds increase of Cyp26b1). We confirmed here, again, that Stra 8 was the most immediate responsive gene after RA stimulation. The germ cell marker genes (Dazl and Pou5f1), early growth response gene (Egr3), and the
RA receptor gene (Rar $\alpha$ ) did not respond to RA, especially not when RA was added to testes tissue culture.

\section{Conclusions}

There are dynamic transcription and translation changes of $c$-kit before and after SSCs' anticipated differentiation. These changes differ between in the cell lines and in the testis. The responses to RA stimulation are different between the cell lines and testis too. As a significant upstream regulatory factor for $c$-kit expression, RA might play with other unknown factors to precisely regulate the expression profiles of $c$-kit in order to regulate normal spermatogenesis.

\section{Additional files}

Additional file 1: Multiple sequence alignment of $c$-kit transcripts. Additional file 2: Multiple sequence alignment of ORF finder predicted c-kit proteins.

\section{Competing interests}

The authors declare that they have no competing interests. 


\section{Authors' contributions}

$\mathrm{LZ}$ and $\mathrm{YH}$ carried out the molecular genetic studies, participated in the RACE, Northern blot, sequence alignment and drafted the manuscript. JT carried out the immunoassays. $\mathrm{CH}$ and HF participated in the design of the study. LL participated online mRNA and protein prediction analysis. XT performed the statistical analysis. All authors read and approved the final manuscript.

\section{Acknowledgement}

This study is funded by Hong Kong RGC grant (464809) to YB Han, Key project No. 12JC1407602 by Science and Technology commission of Shanghai municipality to YB Han.

\section{Author details}

${ }^{1}$ Shanghai first maternity and infant health hospital, Tongji University, Shanghai, China. ${ }^{2}$ Department of Obstetrics and Gynaecology, Prince of Wales hospital, The Chinese University of Hong Kong, Hong Kong, China. ${ }^{3}$ Diagnostics and Reproductive Health Center BGl, Beishan Industrial ZoneYantian District, Shenzhen 518083, China. ${ }^{4}$ Guangzhou Institute of Biomedicine and Health Chinese Academy of Sciences, Guangzhou, China. ${ }^{5}$ Department of Obstetrics and Gynecology, New York University Medical College, Manhasset, NY, USA

Received: 8 May 2013 Accepted: 16 October 2013

Published: 27 October 2013

\section{References}

1. Barroca V, Lassalle B, Coureuil M, Louis JP, Le PF, Testart J, Allemand I, Riou $L$, Fouchet $P$ : Mouse differentiating spermatogonia can generate germinal stem cells in vivo. Nat Cell Biol 2009, 11:190-196.

2. Schrans Stassen BH, De Kant HJ V, De Rooij DG, Van PAM: Differential expression of c-kit in mouse undifferentiated and differentiating type A spermatogonia. Endocrinology 1999, 140:5894-5900.

3. Chabot B, Stephenson DA, Chapman VM, Besmer P, Bernstein A: The protooncogene c-kit encoding a transmembrane tyrosine kinase receptor maps to the mouse W locus. Nature 1988, 335:88-89.

4. Yarden Y, Kuang WJ, Yang Feng T, Coussens L, Munemitsu S, Dull TJ, Chen E, Schlessinger J, Francke U, Ullrich A: Human proto-oncogene c-kit: a new cell surface receptor tyrosine kinase for an unidentified ligand. EMBO J 1987, 6:3341-3351.

5. Blechman JM, Lev S, Barg J, Eisenstein M, Vaks B, Vogel Z, Givol D, Yarden Y: The fourth immunoglobulin domain of the stem cell factor receptor couples ligand binding to signal transduction. Cell 1995, 80:103-113.

6. Blechman JM, Lev S, Givol D, Yarden Y: Structure-function analyses of the kit receptor for the steel factor. Stem Cells 1993, 11(Suppl 2):12-21.

7. Albanesi C, Geremia R, Giorgio M, Dolci S, Sette C, Rossi P: A cell- and developmental stage-specific promoter drives the expression of a truncated c-kit protein during mouse spermatid elongation. Development 1996, 122:1291-1302.

8. Dym M, Jia MC, Dirami G, et al: Expression of c-kit receptor and its autophosphorylation in immature rat type A spermatogonia. Biol Reprod 1995, 52(1):8-19.

9. Gu Y, Runyan C, Shoemaker A, Surani A, Wylie C: Steel factor controls primordial germ cell survival and motility from the time of their specification in the allantois, and provides a continuous niche throughout their migration. Development 2009, 136(8):1295-1303.

10. Guerif F, Cadoret V, Rahal-Perola V, et al: Apoptosis, onset and maintenance of spermatogenesis: evidence for the involvement of Kit in Kit-haplodeficient mice. Biol Reprod 2002, 67(1):70-79.

11. Ohta H, Yomogida K, Dohmae K, Nishimune $Y$ : Regulation of proliferation and differentiation in spermatogonial stem cells: the role of c-kit and its ligand SCF. Development 2000, 127(10):2125-2131.

12. Orth JM, Qiu J, Jester WF Jr, Pilder S: Expression of the c-kit gene is critical for migration of neonatal rat gonocytes in vitro. Biol Reprod 1997, 57(3):676-683.

13. Packer Al, Besmer $P$, Bachvarova RF: Kit ligand mediates survival of type $A$ spermatogonia and dividing spermatocytes in postnatal mouse testes. Mol Reprod Dev 1995, 42(3):303-310.

14. Prabhu SM, Meistrich ML, McLaughlin EA, Roman SD, Warne S, Mendis S, Itman C, Loveland KL: Expression of c-Kit receptor mRNA and protein in the developing, adult and irradiated rodent testis. Reproduction 2006, 131:489-499.

15. Runyan C, Schaible K, Molyneaux K, Wang Z, Levin L, Wylie C: Steel factor controls midline cell death of primordial germ cells and is essential for their normal proliferation and migration. Development 2006, 133(24):4861-4869.

16. Snyder EM, Davis JC, Zhou Q, Evanoff R, Griswold MD: Exposure to Retinoic Acid in the Neonatal but Not Adult Mouse Results in Synchronous Spermatogenesis. Biol Reprod 2011, 84(5):886-893.

17. Yan W, Suominen J, Toppari J: Stem cell factor protects germ cells from apoptosis in vitro. J Cell Sci 2000, 113(Pt 1):161-168.

18. Yoshinaga K, Nishikawa S, Ogawa M, Hayashi S, Kunisada T, Fujimoto T, Nishikawa S: Role of c-kit in mouse spermatogenesis: identification of spermatogonia as a specific site of c-kit expression and function. Development 1991, 113:689-699.

19. Sorrentino V, Giorgi M, Geremia R, Besmer P, Rossi P: Expression of the c-kit proto-oncogene in the murine male germ cells. Oncogene 1991, 6:149-151.

20. Rossi P, Marziali G, Albanesi C, Charlesworth A, Geremia R, Sorrentino V: A novel c-kit transcript, potentially encoding a truncated receptor, originates within a kit gene intron in mouse spermatids. Dev Biol 1992, 152:203-207.

21. Sette C, Bevilacqua A, Bianchini A, Mangia F, Geremia R, Rossi P: Parthenogenetic activation of mouse eggs by microinjection of a truncated c-kit tyrosine kinase present in spermatozoa. Development 1997, 124:2267-2274.

22. Sette C, Dolci S, Geremia R, Rossi P: The role of stem cell factor and of alternative c-kit gene products in the establishment, maintenance and function of germ cells. Int J Dev Biol 2000, 44:599-608.

23. Kubota $H$, Avarbock MR, Schmidt JA, Brinster RL: Spermatogonial stem cells derived from infertile $\mathrm{Wv} / \mathrm{Wv}$ mice self-renew in vitro and generate progeny following transplantation. Biol Reprod 2009, 81:293-301.

24. Morimoto H, Kanatsu Shinohara M, Takashima S, Chuma S, Nakatsuji N, Takehashi M, Shinohara T: Phenotypic plasticity of mouse spermatogonial stem cells. PLoS One 2009, 4:e7909.

25. Nakagawa T, Sharma M, Nabeshima Y, Braun RE, Yoshida S: Functional hierarchy and reversibility within the murine spermatogenic stem cell compartment. Science 2010, 328:62-67.

26. Shinohara T, Orwig KE, Avarbock MR, Brinster RL: Spermatogonial stem cell enrichment by multiparameter selection of mouse testis cells. Proc Natl Acad Sci U S A 2000, 97:8346-8351.

27. Suzuki H, Sada A, Yoshida S, Saga Y: The heterogeneity of spermatogonia is revealed by their topology and expression of marker proteins including the germ cell-specific proteins Nanos2 and Nanos3. Dev Biol 2009, 336:222-231

28. Yoshida S, Sukeno M, Nakagawa T, Ohbo K, Nagamatsu G, Suda T, Nabeshima $Y$ : The first round of mouse spermatogenesis is a distinctive program that lacks the self-renewing spermatogonia stage. Development 2006, 133:1495-1505.

29. Heim C, Minniear K, Dann CT: Imatinib has deleterious effects on differentiating spermatogonia while sparing spermatogonial stem cell self renewal. Reprod Toxicol 2011, 31:454-463.

30. Trefil P, Bakst MR, Yan H, Hejnar J, Kalina J, Mucksova J: Restoration of spermatogenesis after transplantation of c-Kit positive testicular cells in the fowl. Theriogenology 2010, 74:1670-1676.

31. Izadyar F, Pau F, Marh J, Slepko N, Wang T, Gonzalez R, Ramos T, Howerton K, Sayre C, Silva F: Generation of multipotent cell lines from a distinct population of male germ line stem cells. Reproduction 2008, 135:771-784.

32. Jones Villeneuve EM, McBurney MW, Rogers KA, Kalnins VI: Retinoic acid induces embryonal carcinoma cells to differentiate into neurons and glial cells. J Cell Biol 1982, 94:253-262.

33. Livera G, Rouiller-Fabre V, Pairault C, Levacher C, Habert R: Regulation and perturbation of testicular functions by vitamin A. Reproduction 2002, 124:173-180.

34. Bowles J, Knight D, Smith C, Wilhelm D, Richman J, Mamiya S, Yashiro K, Chawengsaksophak K, Wilson MJ, Rossant J, et al: Retinoid signaling determines germ cell fate in mice. Science 2006, 312:596-600.

35. Koubova J, Menke DB, Zhou Q, Capel B, Griswold MD, Page DC: Retinoic acid regulates sex-specific timing of meiotic initiation in mice. Proc Natl Acad Sci U S A 2006, 103:2474-2479.

36. Morales C, Griswold MD: Retinol-induced stage synchronization in seminiferous tubules of the rat. Endocrinology 1987, 121(1):432-434. 
37. Van PAM, De Rooij DG: Retinoic acid is able to reinitiate spermatogenesis in vitamin A-deficient rats and high replicate doses support the full development of spermatogenic cells. Endocrinology 1991, 128:697-704

38. Hofmann MC, Braydich-Stolle L, Dettin L, Johnson E, Dym M: Immortalization of mouse germ line stem cells. Stem Cells 2005, 23:200-210.

39. Hofmann MC, Narisawa S, Hess RA, Millan JL: Immortalization of germ cells and somatic testicular cells using the SV40 large T antigen. Exp Cell Res 1992, 201:417-435.

40. Hofmann MC, Abramian D, Millan JL: A haploid and a diploid cell coexist in an in vitro immortalized spermatogenic cell line. Dev Genet 1995, 16:119-127.

41. Hofmann MC, Hess RA, Goldberg E, Millan JL: Immortalized germ cells undergo meiosis in vitro. Proc Natl Acad Sci U S A 1994, 91:5533-5537.

42. Zhou Q, Li Y, Nie R, Friel P, Mitchell D, Evanoff RM, Pouchnik D, Banasik B, McCarrey JR, Small C, et al: Expression of stimulated by retinoic acid gene 8 (Stra8) and maturation of murine gonocytes and spermatogonia induced by retinoic acid in vitro. Biol Reprod 2008, 78:537-545.

43. Shinohara T, Avarbock MR, Brinster RL: beta1- and alpha6-integrin are surface markers on mouse spermatogonial stem cells. Proc Natl Acad SCi U S A 1999, 96:5504-5509.

44. Wang Y, Culty M: Identification and distribution of a novel plateletderived growth factor receptor beta variant: effect of retinoic acid and involvement in cell differentiation. Endocrinology 2007, 148(5):2233-2250.

45. Pellegrini $\mathrm{M}$, Filipponi $\mathrm{D}$, Gori $\mathrm{M}$, et al: ATRA and KL promote differentiation toward the meiotic program of male germ cells. Cell Cycle 2008, 7(24):3878-3888.

doi:10.1186/1471-213X-13-38

Cite this article as: Zhang et al.: c-kit expression profile and regulatory

factors during spermatogonial stem cell differentiation. $B M C$

Developmental Biology 2013 13:38.

\section{Submit your next manuscript to BioMed Central and take full advantage of:}

- Convenient online submission

- Thorough peer review

- No space constraints or color figure charges

- Immediate publication on acceptance

- Inclusion in PubMed, CAS, Scopus and Google Scholar

- Research which is freely available for redistribution 